\title{
Gape size influences seasonal patterns of piscivore diets in three Neotropical rivers
}

\author{
Carmen G. Montaña ${ }^{1}$, Craig A. Layman ${ }^{2}$ and Kirk O. Winemiller ${ }^{1}$
}

We examined diets of four piscivores, two in the order Perciformes (Cichla temensis and C. orinocensis) and two in the order Characiformes (Boulengerella cuvieri and B. lucius), from the Cinaruco, La Guardia, and Ventuari rivers in Venezuela throughout the wet-dry seasonal cycle. The four piscivores consumed a phylogenetically and morphologically diverse group of fishes, reflecting the overall diversity of fish species in these rivers. At the start of the falling-water period, Cichla consumed large prey, especially the abundant, migratory, fish of the genus Semaprochilodus. As these relatively large prey became depleted during the dry season, Cichla tended to consume smaller prey. For Boulengerella, gape limitation precluded consumption of larger, seasonally abundant, fishes, and so prey sizes were more consistent throughout the seasonal cycle. Our findings show how prey abundance and gape limitations interact to influence seasonal patterns of predator-prey interactions.

Foram examinadas as dietas de quatro espécies de peixes piscívoros, duas da ordem Perciformes (Cichla temensis and $C$. orinocensis) e duas da ordem Characiformes (Boulengerella cuvieri and B. lucius), coletadas durante os ciclos de cheia e seca nos rios Cinaruco, La Guardia e Ventari, Venezuela. Os quatro piscívoros consumiram grupos de peixes filogenética e morfologicamente diversos, o que reflete a ampla diversidade de peixes nos rios estudados. No início da vazante, Cichla consumiu presas grandes, especialmente Semaprochilodus, um peixe migrador muito abundante. Com a diminuição das presas maiores durante a estação seca, Cichla tendeu a se alimentar de presas menores. Para Boulengerella, a limitação da abertura bucal impediu o consumo de peixes grandes e sazonalmente abundantes e, deste modo, o tamanho de suas presas foi menos variável ao longo do ciclo sazonal. Nossos resultados mostram como a abundância das presas e a limitação na abertura bucal interagem, influenciando os padrões de interação predador-presa.

Key words: Floodplain river, Food web, Optimal foraging theory, Predator-prey interaction, Venezuela.

\section{Introduction}

Predatory fishes affect prey diversity and abundance in aquatic ecosystems, and thus can influence community structure and ecosystem function (Zaret, 1980). Predator-prey interactions are determined by morphological constraints such as predator and prey body size (Paine, 1976) and gape limitation (Hambright, 1991), which affect the efficiency of prey capture (Gill, 2003) and handling time (Hoyle \& Keast, 1987). As such, body size is an important predictor of the maximum potential prey size that a given predator can consume. For example, Mittelbach \& Persson (1989) found that sizes of prey consumed by 34 freshwater piscivores were largely determined by differences in piscivore body size. Similarly, Hambright et al. (1991) found that largemouth bass,
Micropterus salmoides, never ingested prey that were greater than their mouth width, but did take prey that were as large as their own body depth. In general, a prey item can be captured and eaten if the prey/predator body size ratio is within a specific range, i.e., the 'predation window' (Claessen et al., 2002).

Environmental conditions are also primary determinants of predator-prey dynamics (Navarrete \& Manzur, 2008), and can moderate the relative importance of body-size based mechanisms in determining prey selection (Jennings \& Warr, 2003). In tropical floodplain rivers, a distinct seasonal hydrological cycle provides the context in which predatorprey dynamics are set (Jepsen et al., 1997; Rodríguez \& Lewis, 1997; Layman et al., 2005). During high water, fish and other aquatic organisms are widely dispersed (Lowe-McConnell,

\footnotetext{
${ }^{1}$ Texas A\&M University, Department of Wildlife and Fisheries Sciences, College Station, TX 77843-2258.car1607@tamu.edu, k-winemiller@tamu.edu

2Florida International University, Marine Sciences Program. North Miami, Florida 33181. cal1634@yahoo.com
} 
1987). As water levels fall, prey densities increase, biotic interactions become more intense, and predation may drive many community-and-ecosystem-level processes (Layman \& Winemiller, 2004). During the falling-water, piscivore feeding rates and growth may increase (Jepsen et al., 1999) as prey are forced from the flooded forests and savannas into the main river channel. Changing water levels are also associated with spawning migrations of benthivorous prochilodontid fish, some of which provide important energy subsidies to predators in relatively nutrient-poor systems (Winemiller \& Jepsen, 1998; Hoeinghaus et al., 2006).

In this study, we examined dietary patterns of four piscivores, two belonging to the family Cichlidae (Cichla temensis and $C$. orinocensis) and two in the family Ctenoluciidae (Boulengerella cuvieri and B. lucius) in three Neotropical rivers that have a distinct wet-dry seasonal hydrology. We examined prey size in relation to predator gape width, and explored how gape limitations may mediate seasonal patterns of predator-prey dynamics

\section{Materials and Methods}

\section{Study site}

The study was conducted in three floodplain rivers with similar seasonal hydrology: Cinaruco, La Guardia, and Ventuari (Fig. 1). The Cinaruco and La Guardia rivers are moderate blackwater rivers within Venezuelan's Santo Luzardo National Park, in Apure State. Blackwater rivers in this region are characterized by low nutrient concentrations, low $\mathrm{pH}$, sandy bottoms, and scattered floodplain lagoons (Montoya et al., 2006). Fish diversity ( $>300$ species) is high, and fishes display a wide range of ecological attributes and life history strategies (Layman et al., 2005). These two rivers are characterized by a strongly seasonal hydrology with water levels typically fluctuating $>5 \mathrm{~m}$ during an annual hydrological cycle (Arrington \& Winemiller,2006; Layman et al., 2010). The Ventuari River is a tributary of the Orinoco River in Venezuela's Amazonas State characterized by clear water, low $\mathrm{pH}$, and high fish diversity (> 400 fish species, Montaña et al., 2005). In each river, during the wet season (May to October) the riparian forests and adjacent savannas are flooded and organisms are dispersed widely throughout the floodplain. Water begins receding during November, with lowest water levels occurring in February and March (Arrington \& Winemiller, 2006; Winemiller et al., 2006, Montaña \& Winemiller, 2009). As water levels fall, aquatic organisms are forced into the main channels and associated littoral habitats, which exposes them to high risk of predation (Layman \& Winemiller, 2004).

\section{Piscivore species}

Two species of large piscivorous cichlids in the order Perciformes (Cichla temensis Humboldt, 1821 and Cichla orinocensis Humboldt, 1821) and two species of large piscivorous pike characins in the order Characiformes (Boulengerella cuvieri Spix \& Agassiz, 1829 and B. lucius
Cuvier, 1816) were examined. Cichla species have large, wide, gapes, and an elongate and laterally compressed body (Fig. 2). Boulengerella has an elongate body, elongated-narrow snout, and relatively small gape (Fig. 2).

\section{Fish Sampling}

For all three rivers, sampling was conducted in both lagoons and the main channel from October to May 20022005. Sampling included three important periods of the annual hydrological cycle: the descending limb (October-December), low water period (February-March) and ascending limb (AprilMay) (for more detail on this seasonal hydrology, see Arrington \& Winemiller, 2006; Montoya et al. 2006, Winemiller et al., 2006). Sampling effort and frequency were not equal among rivers and varied among years and months due to logistical considerations. Cichla and Boulengerella were collected with gill nets, cast nets, and by angling with artificial lures. Stomach contents of Cichla were removed by pressing down the posterior region of the tongue and pushing gently on the fish's stomach while holding the fish in a head-down position (Layman et al., 2005). Specimens of Boulengerella were euthanized, preserved in 10\% formalin, and transported to the laboratory at the Museo de Ciencias Naturales Guanare (MCNG) where the stomachs were removed for examination. Predator and prey fishes were measured to the nearest $1.0 \mathrm{~mm}$ standard length (SL). Stomach contents were identified to the lowest feasible taxonomic level and quantified volumetrically following Winemiller's (1990) method. Voucher specimens are archived in the Museo de Ciencias Naturales at UNELLEZ, Guanare, Venezuela, and the Texas Cooperative Wildlife Collection, College Station, Texas, USA (Boulengerella cuvieri : MCNG 3095, 3277, 9659, 13458, 17268, 17268, 20153, 30895, 31208, 34692, 38721, 39167, 39202, 39667, $39736,41667,43824,43989,44269,44453,45068,47071,52482$, 53069, 54853, 54960, 54960, 55073, 55181 and B. lucius: $\mathrm{MCNG}$ 17966, 21790, 26502, 29497, 31007, 35406, 35492, 35835, 39688,

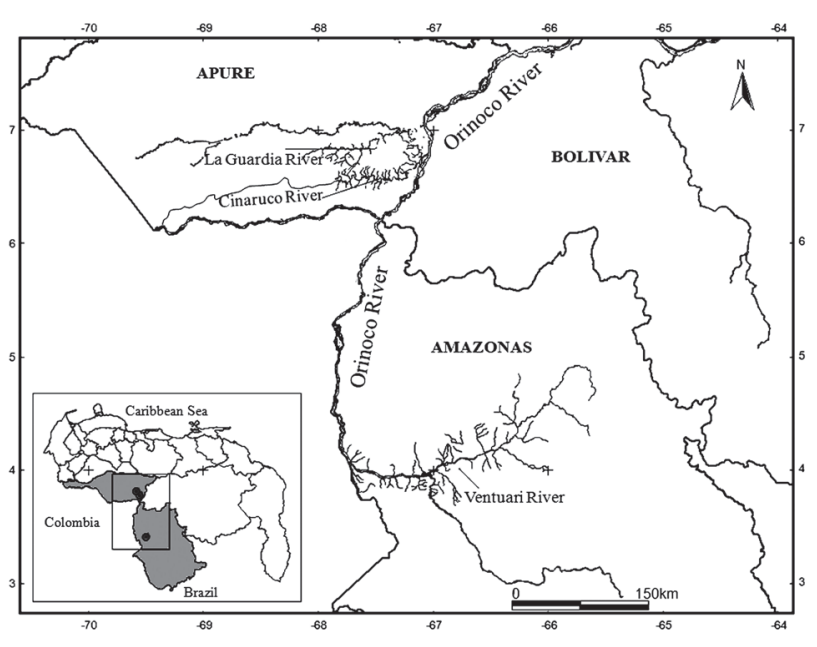

Fig. 1. Map of Venezuela showing the locations of the three tributaries of the Orinoco River considered in this study: La Guardia, Cinaruco, and Ventuari Rivers. 
40942,40956, 42376, 43432,46291,46544,46614,46955, 47160, $47176,51610,51689,52477,52481)$.

Gape width was measured in a subset of Cichla $(C$. temensis $=47$ individuals, $C$. orinocensis $=37$ individuals) and Boulengerella $($ B. cuvieri $=36$ individuals, $B$. lucius $=35$ individuals) with calipers to the nearest $0.1 \mathrm{~mm}$. These data were used to create a regression between predator SL and gape width, which was then used to estimate gape sizes for additional field caught specimens based on their measured standard lengths.

\section{Prey availability}

To provide one example of potential seasonal patterns in prey availability (logistical constraints prevented us from sampling all systems), we surveyed fishes on 7 sandbanks in the main channel and along the shoreline of 8 lagoons in the Cinaruco River from November 2002 (start of falling water levels) to April 2003 (end of the dry season). For each collection, a seine $(6.4 \mathrm{~m} \times 1.8 \mathrm{~m}$ with $4 \mathrm{~mm}$ mesh) was oriented parallel to shore. The seine hauls were initiated from a depth up to $\sim 1.5 \mathrm{~m}$ depth, and the haul was terminated at the shoreline. At each site, three non-overlapping seine hauls comprised a sample. All fishes were identified to species, enumerated, and measured to the nearest $1.0 \mathrm{~mm}$ SL. Fish sizes were used to construct a frequency histogram of prey

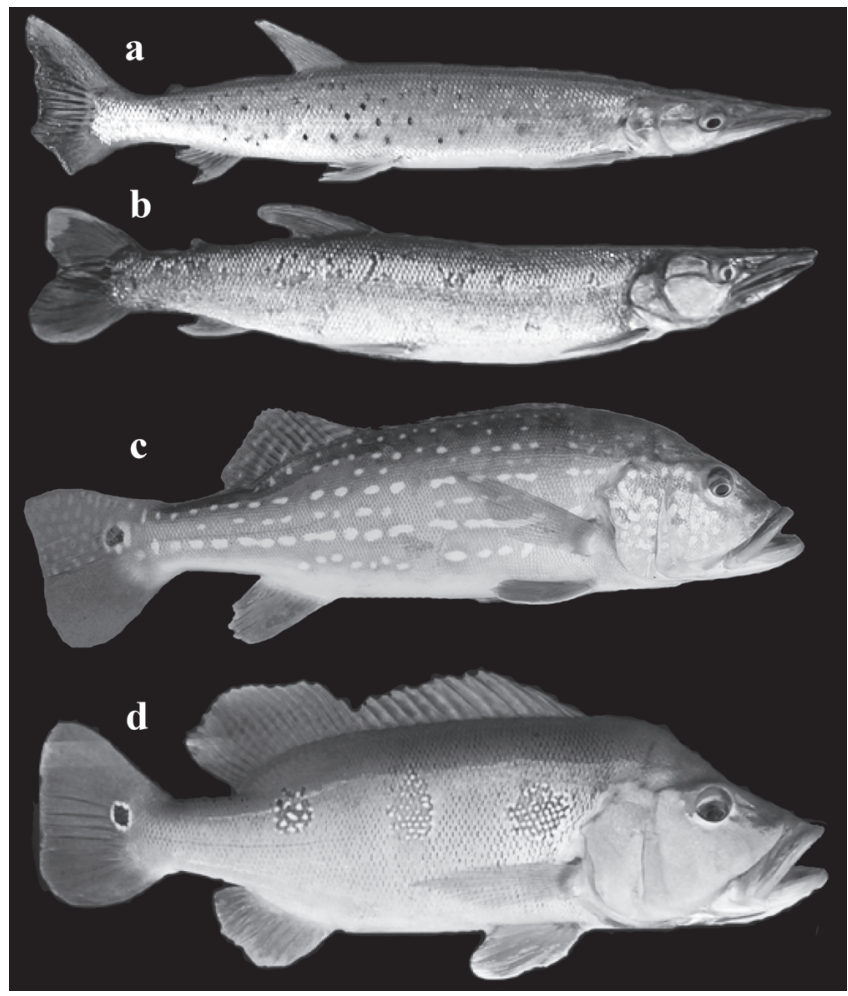

Fig. 2. Photographs of representative individuals of the focal species in this study (not preserved). From top: a) Boulengerella cuvieri $(\mathrm{SL}=320 \mathrm{~mm})$, b) Boulengerella lucius $(\mathrm{SL}=420 \mathrm{~mm})$, c) Cichla temensis $(\mathrm{SL}=360 \mathrm{~mm})$, d) Cichla orinocensis $(\mathrm{SL}=305 \mathrm{~mm})$. fishes collected in the main channel and lagoons.

\section{Statistical analysis}

Prey identified from stomach contents were used to examine seasonal patterns of prey-predator body size ratios. Univariate regressions were conducted with Sigma Stat (1997) to test for variability in prey/predator body sizes across hydrological seasons. One-way ANOVA was performed with SPSS 16.0 (2007) to test whether predators SL, predator's gape width and prey consumed SL differ significantly between genera. To examine prey fish composition in the littoral zone, we measured the body length (SL) of fish collected in lagoons and main channel. Samples were pooled according to habitat type for each month. Frequency histograms of prey fishes were performed and compared between hydrological seasons. Analysis of similarity (ANOSIM, Clarke \& Warwick, 1994) was used to test for differences of fish composition in lagoons and main-channel sand banks for this data set.

\section{Results}

We analyzed 4,761 individual stomachs of Cichla and Boulengerella, and identified 8 orders, 24 families, 53 genera, and 73 species of prey fish (Appendix 1). The number of prey fish consumed varied between piscivore genera: 69 prey taxa were identified in stomachs of Cichla and 21 in Boulengerella. Characids (e.g., genera Bryconops, Hemigrammus, Moenkhausia), hemiodontids, and the prochilodontid Semaprochilodus kneri were the most common prey consumed by Cichla. Semaprochilodus kneri (a relatively deep bodied fish) was found only in Cichla stomachs, whereas small characids $(<40 \mathrm{~mm})$ were the most common prey of Boulengerella (Appendix 1).

Predator standard length and gape width were strongly related (C. temensis: Gape $=0.15 \mathrm{SL}-1.01\left[\mathrm{R}^{2}=0.90\right], C$.

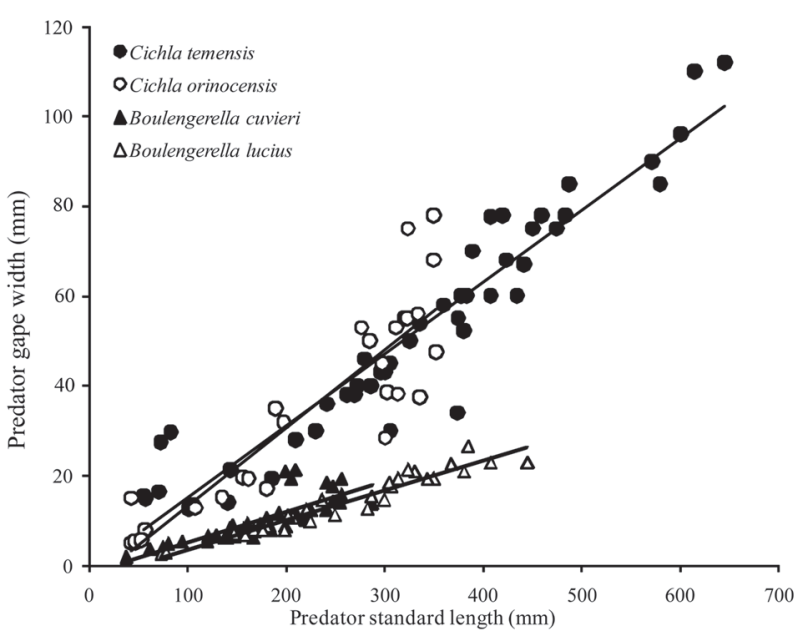

Fig. 3. Relationship between standard length and gape width for the four predator species. 
orinocensis: $\mathrm{Gape}=0.17 \mathrm{SL}-4.31\left(\mathrm{R}^{2}=0.83\right]$, B. lucius: Gape $=$ $\left.0.06 \mathrm{SL}-3.01\left[\mathrm{R}^{2}=0.93\right]\right)$, and B. cuvieri: Gape $=0.06 \mathrm{SL}-1.70$ $\left.\left[\mathrm{R}^{2}=0.65\right]\right)$. Both Cichla species had a larger gape than Boulengerella species at a given standard length (ANOVA, $\mathrm{F}_{3{ }^{\prime}, 154}=46.2, \mathrm{P}=0.0001$; Fig. 3 ). Similarly, there were statistically significant differences in fishes of prey consumed by Cichla and Boulengerella $\left(\mathrm{F}_{3,320}=16.09, \mathrm{P}=0.0001\right)$. Cichla temensis fed on larger prey (range 2-255 mm, mean+/-S.D., 60.6+/-40.6) than its congener C. orinocensis (1.5-125 mm, 38.7+/-29.6). Boulengerella lucius and B. cuvieri consumed smaller prey, ranging from $15-85 \mathrm{~mm}(30.6+/-15.1)$ in B. lucius and 3-95 mm (27.8+/-15.1) in B. cuvieri (Fig. 4).

Variation in prey-predator body size ratios was observed through the hydrological cycle. Cichla (C. temensis, $\mathrm{r}^{2}=0.2$, $\mathrm{p}<0.001 ;$ C. orinocensis, $\mathrm{r}^{2}:=0.1, \mathrm{p}<0.07$, Fig. 5). Ratios tended to be higher during the early falling water phase and lower during the low-water phase (Jan/Apr). Seasonal variation in
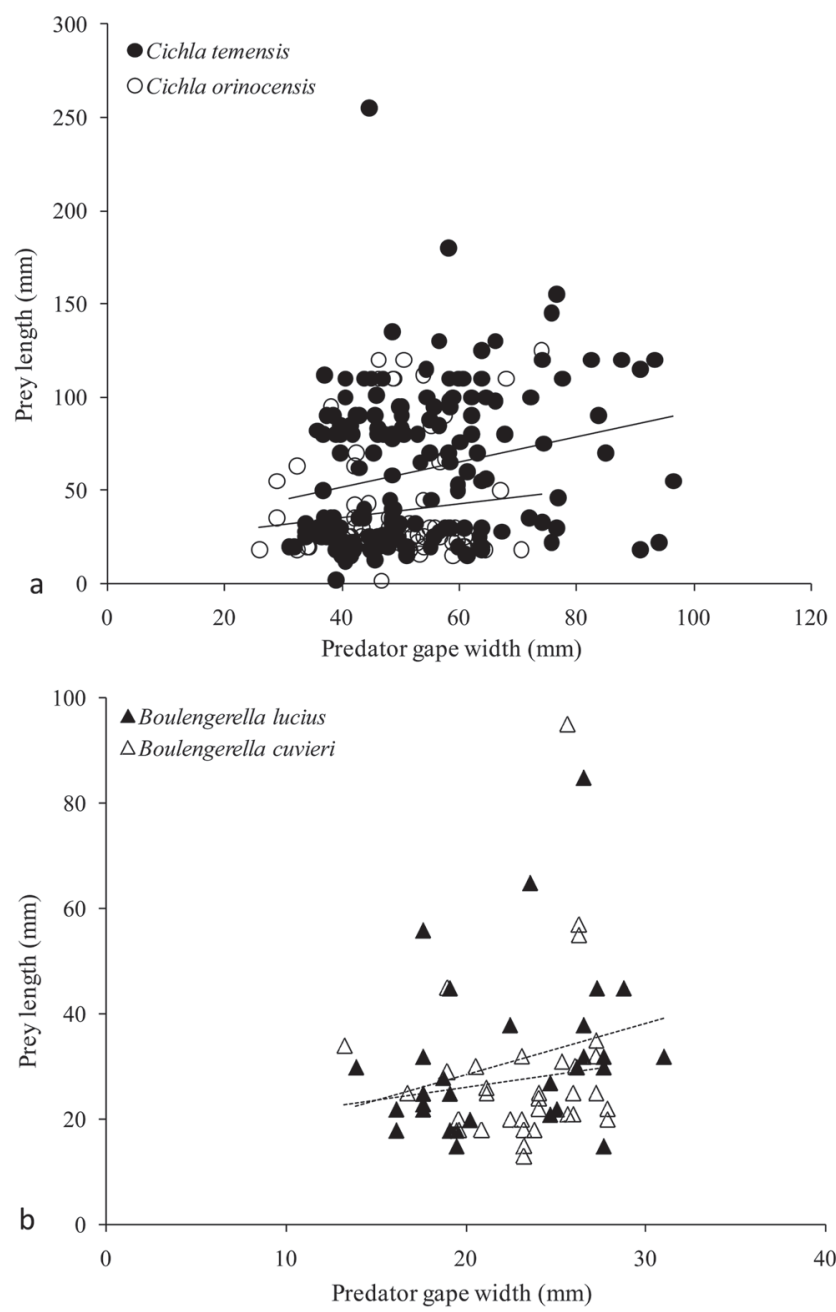

Fig. 4. Relationship between estimated predator gape width (from Fig. 3) and measured prey length size. Significant relationships are represented by solid lines and non-significant relationships with dotted lines. a) $C$. temensis and $C$. orinocensis; b) B. lucius and B. cuvieri . ratios was not significant for Boulengerella (for both species, $\mathrm{p}>0.2$ ).

Monthly seine haul samples from the Cinaruco River yielded a total of 13,846 fishes of 58 species; the mean value of the largest $5 \%$ of fish (calculated across all species) tended to decline as the water level fell during the dry season. This trend was significant for lagoons $\left(F_{1,5}=17.0, P=0.015, r^{2}=\right.$ $0.81)$ but not for the main channel $\left(F_{1,4}=2.6, P=0.20, r^{2}=0.46\right)$ (Fig. 5). Assemblage composition in the main-channel differed significantly among months (ANOSIM, $\mathrm{R}=0.29, P<0.001$ ). This difference was due to fewer individuals of relatively large species (e.g., Bryconops spp. and Hemiodus spp.) as water levels fell. Additionally, a few juvenile fishes appeared in samples just before the onset of the wet season (Apr/May). Lagoon assemblages were characterized by a similar, although non-significant, trend (ANOSIM, $\mathrm{R}=0.02, P=0.37$ ).

\section{Discussion}

Piscivores examined in this study were found to consume phylogenetically and morphologically diverse fish taxa that reflect the overall diversity of fishes in these floodplain rivers. Even within individual piscivore species, prey varied broadly in terms of body size and other phenotypic traits, with body size likely a primary determinant of emergent trends. Based on gape width, there was a tendency for Cichla to consume a large size range of prey, including migratory hemiodontids and semaprochilodontids (Appendix 1) that are abundant during the falling-water cycle (Layman \& Winemiller, 2005). In contrast, Boulengerella consumed primarily small-bodied characids throughout the seasonal cycle, likely because of gape constraints.

Seasonal shifts in prey availability appear to drive the seasonal decline in the size of prey consumed by Cichla. For example, larger prey were more abundant as waters began to fall (Fig. 5a), but they became less abundant through the dry season likely due to predator-induced mortality. Piscivores encounter large prey relatively less frequently during the lowwater period, resulting in the seasonal shift in prey/predator body size ratios for Cichla species.

In South American rivers, the annual flood pulse is associated with fish migrations (Lowe-McConnell, 1987). During the falling-water period, large predators apparently increase foraging activities with preference for large prey, many of which are those migrating from the Orinoco River into tributaries (Winemiller \& Jepsen, 1998). In the Cinaruco River, the diet of Cichla temensis contains about 50\% Semaprochilodus ( $>40 \mathrm{~mm} \mathrm{SL}$ ) by volume during the falling water period (Jepsen et al., 1997). Similarly, dietary and isotope analyses support the conclusion that Cichla species have greater body condition during the falling-water period (Hoeinghaus et al., 2006).

Prey selection may arise through either active or passive processes (Turesson et al., 2002). Predators that primarily feed on mobile prey may show little or no active choice among prey taxa (Juanes \& Conover, 1994; Christensen, 1996; Scharf 


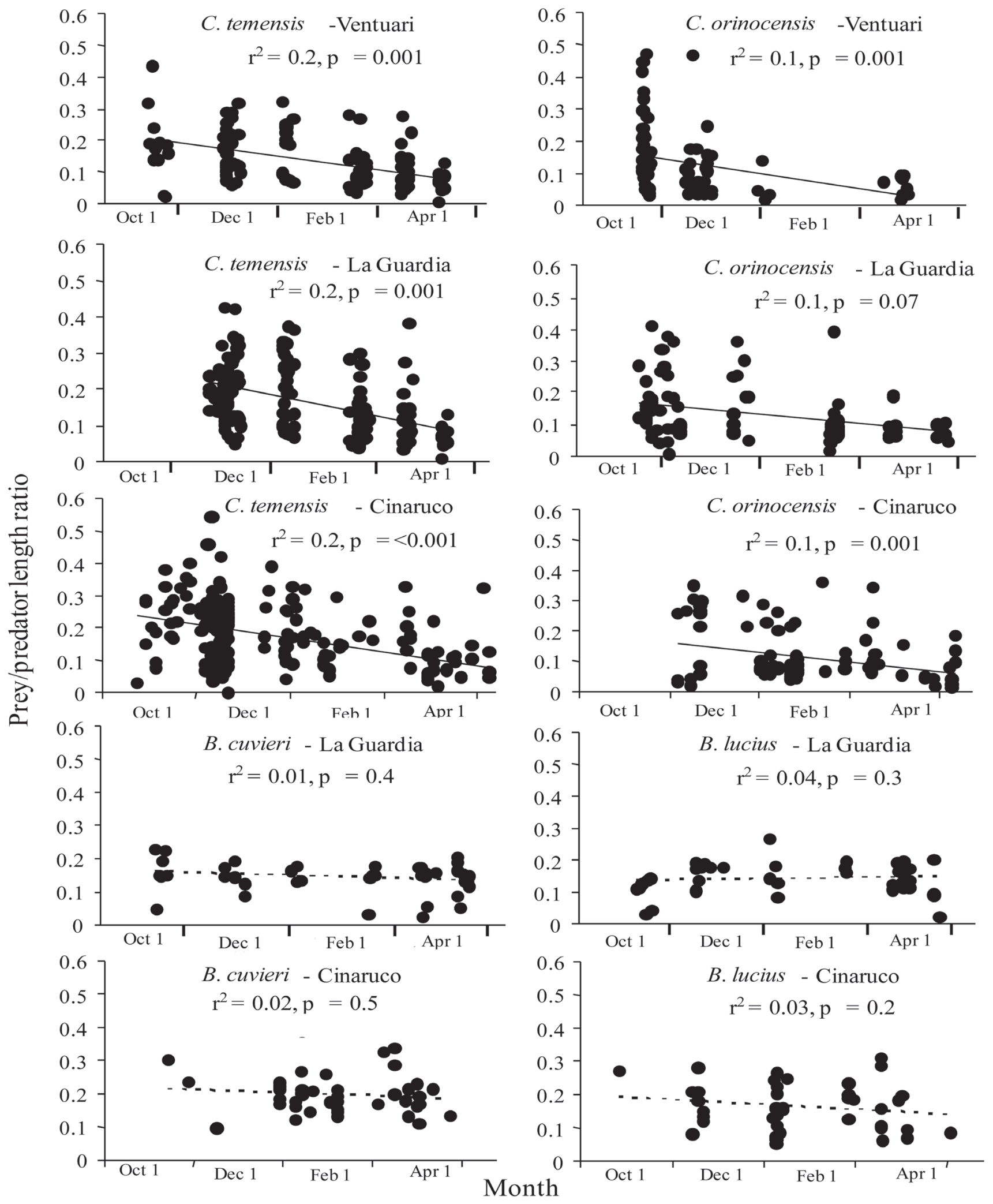

Fig. 5. Prey/predator body length ratios for four predator species. Relationships are presented from falling water (October) to rising water (May) period. Significant relationships are represented by a solid line and non-significant relationships with dotted lines. Number of stomach contents examined during the study period: Ventuari: C. temensis $=408$, . orinocensis $=698$; Cinaruco: C. temensis $=1365$, C. orinocensis $=755$, B. cuvieri $=292$, B. lucius $=411$; La Guardia: . temensis $=444, C$. orinocensis $=228$, B. cuvieri $=93$, B. lucius $=67$. 


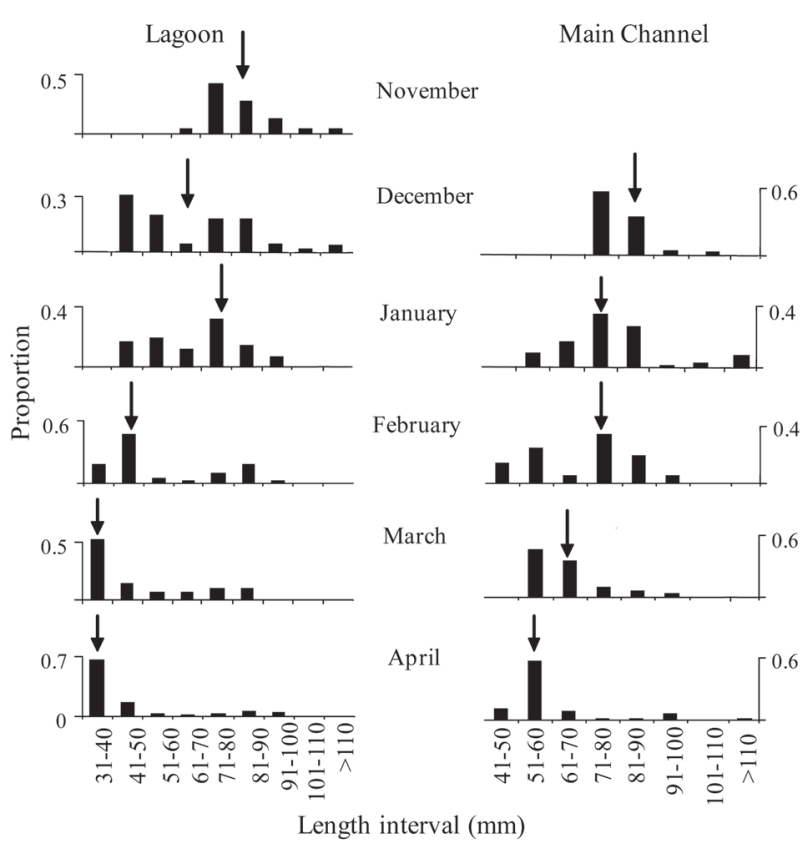

Fig. 6. Frequency histogram of the largest (SL) 5\% of individuals collected each month in seine hauls. Larger individuals became increasingly rare from November to April as water levels fall. Arrows indicate the median size for each month.

et al., 1998), and thus prey selection may be driven largely by differences in prey encounter rates (partially a function of prey availability) and capture probabilities. The range of prey species consumed by piscivores in this study is consistent with the idea that prey selection is largely passive in this system, especially in periods when the large hemiodontids and migratory semiprochilodontids are not abundant.

Predation mortality is very high in tropical floodplain systems (Rodriguez \& Lewis, 1997), and thus predators likely induce changes in the fish community (Jepsen et al., 1997; Jepsen \& Winemiller, 1999; Hoeinghaus et al., 2006), which in turn results in a shift in predator-prey interactions (Winemiller, 1989; Gratwicke \& Marshal, 2001). Although prey selection by piscivores is a function of many factors, including speciesspecific traits and spatial variability (e.g., differential predator and prey densities in patchy habitats), there nonetheless are general patterns of predation that provide a foundation for predicting predator-prey dynamics in species-rich tropical food webs. Our study highlights the importance of size relationships between piscivores and their prey over a seasonal hydrological cycle, which may help to predict preypredator interactions.

\section{Acknowledgments}

The Cinaruco River Fishing Club and Tour Apure provided logistical support in Cinaruco River. Jay Roff provided logistical and economical support through the La Guardia Camp. Some data were provided by David Jepsen and Albrey Arrington. Foundation Cisneros provided logistical support to Carmen Montaña as part of her master thesis. Donald Taphorn at UNELLEZ provided logistical support and helped with fish identification. Fish collections were made with fishing permits issued by the Servicio Autonomo de los Recursos Pesqueros y Acuicolas of Venezuela. This work also received support from the U.S. Environmental Protection Agency Science Graduate Fellowship, Texas A\&M Regents and Tom Slick Fellowships. Neotropical Grassland Conservancy supported field work in the Ventuari River.

\section{Literature cited}

Arrington, D. A. \& K. O. Winemiller. 2006. Habitat affinity, the seasonal flow pulse, and community assembly in littoral zone of a Neotropical floodplain river. Journal of North America Benthological Society, 25:126-141.

Christensen, B. 1996. Predator foraging capabilities and prey antipredator behaviors: pre- versus postcapture constraints on size-dependent predator-prey interactions. Oikos, 76:368-380.

Claessen, D., C. Van Oss, A. M. de Ross \& L. Persson. 2002. The impact of size-dependent predation population dynamics and individual life history. Ecology 83:1660-1675.

Clarke, K. R. \& W. M. Warwick. 1994. Similarity-based testing for community pattern: the 2-way layout with no replication. Marine Biology 118:167-176.

Gill, A. B. 2003. The dynamics of prey choice in fish: the importance of prey size and satiation. Journal of Fish Biology, 63 (Suppl. A):105-116.

Gratwicke, B. \& B. E. Marshal. 2001. The relationship between the exotic predators Micropterus salmoides and Serranochromis robustus and native stream fishes in Zimbabwe. Journal of Fish Biology, 58: 68-75

Hambright, D. K. 1991.Experimental analysis of prey selection by largemouth bass: role of predator mouth width and prey body size. Transactions of American Fishery Society, 120:500-508.

Hoeinghaus, D., C. A. Layman, D. A. Arrington \& K. O. Winemiller. 2006. Effects of seasonality and migratory prey on body condition of Cichla species in a tropical floodplain river. Ecology of Freshwater Fish, 15:398-407.

Hoyle, J. A. \& A. Keast. 1987. The effect of prey morphology and size on handling time in a piscivore, the largemouth bass (Micropterus salmoides). Canadian Journal of Zoology, 65:19721977.

Jennings, S. \& K. J. Warr. 2003. Smaller predator-prey body size ratios in longer food chains. Proceedings of the Royal Society of London Series B, 270:1413-1417.

Jepsen, D. B., K. O. Winemiller \& D. C. Taphorn. 1997. Temporal patterns of resource partitioning among Cichla species in a Venezuelan blackwater river. Journal of Fish Biology, 51:10851108

Jepsen, D. B, K. O. Winemiller, D. C. Taphorn \& D. Rodriguez. 1999. Age structure and growth of peacock cichlids from rivers and reservoirs of Venezuela. Journal of Fish Biology, 55: 13111320 .

Juanes, F. \& D. O. Conover. 1994. Piscivory and prey size selection in young of-the-year bluefish: predator preference or sizedependent capture success? Marine Ecology Progress Series, 114:59-69. 
Layman, C.A. \& Winemiller, K.O. 2004. Size-based responses of prey to piscivore exclusion in a Neotropical river. Ecology, 85:1311-1320.

Layman, C. A. \& K. O. Winemiller. 2005. Patterns of habitat segregation among large fishes in a Venezuela floodplain river. Neotropical Ichthyology, 3:111-117.

Layman, C.A., C. G. Montaña \& J. E. 2010. Linking fish colonization rates and water level change in littoral habitat of a Venezuela floodplain river. Aquatic Ecology, 44:269-273.

Layman, C. A., K. O. Winemiller, D. A. Arrington \& Jepsen. 2005. Body size and trophic position in a diverse tropical food web. Ecology, 86:2530-2535.

Lowe-McConnell, R. H. 1987. Ecological Studies in Tropical Fish Communities. Cambridge University Press. London, 382p.

Mittelbach, G. G. \& L. Persson. 1998. The ontogeny of piscivory and its ecological consequences. Canadian Journal of Fishery Aquatic Science, 55:1454-1465.

Montaña, C., G. D. C. Taphorn, L. Nico, C. A. Lasso, O. LeónMata, A. Giraldo, O. Lasso-Alcalá, C. Do Nascimiento, N. Milani. 2005. Fishes of the Ventuari River Basin, Amazonas state (Venezuela). Pp. 123-128. In: Lasso, C. A., J. C. Señaris, L. E. Alonsi \& A. Flores (Eds,). RAP Bulletin of Biological Assessment, Conservation International, Washington D.C., $244 \mathrm{p}$.

Montaña, C. G. \& K. O. Winemiller. 2009. Comparative feeding ecology and habitat use of Crenicichla species (Perciformes: Cichlidae) in a Venezuelan floodplain river. Neotropical Ichthyology, 7:267-274.

Montoya, J. V., D. L. Roelke, K. O. Winemiller, J. B. Cotner \& J. A. Snider. 2006. Hydrological seasonality and benthic algal biomass in a Neotropical floodplain river. Journal of the North American Benthological Society, 25:157-170.
Navarrete, S. \& T. Manzur. 2008. Individual-and population-level responses of keystone predator to geographic variation in prey. Ecology, 89: 2005-2018.

Paine, R. T. 1976. Size-limited predation: an observational and experimental approach with Mytilus-Pisaster interaction. Ecology, 57:858-873.

Rodriguez, M. A. \& W. M. Jr., Lewis. 1997. Structure of fish assemblages along environmental gradients in floodplain lakes of the Orinoco River. Ecological Monographs, 67: 109-128.

Scharf, F. S., B. A. Buckel, F. Juanes \& D. O. Conover. 1998. Predation by juvenile piscivorous bluefish (Pomatomus saltatrix): the influence of prey to predator size ratio and prey type on predator capture success and prey profitability. Canadian Journal of Fish Aquatic Science, 55:1695-1703.

SigmaStat 1997. SigmaStat for Windows Version 2.03. SPSS, Inc.

Turesson, H., A. Persson \& C. Brönmark. 2002. Prey size selection in piscivorous pikeperch (Stizostedion lucioperca) includes active prey choice. Ecology of Freshwater Fish, 11:223-233.

Winemiller, K. O. 1989. Ontogenetic diet shifts and resource partitioning among piscivorous fishes in the Venezuelan llanos. Environmental Biology of Fishes, 26:177-199

Winemiller, K. O. \& D. B. Jepsen. 1998. Effects of seasonality and fish movement on tropical river food webs. Journal of Freshwater Fish Biology, 53:267-296.

Winemiller, K. O., J. V. Montoya, D. L. Roelke, C. A. Layman \& J. B. Cotner. 2006. Seasonal varying impact of detritivorous fishes in the benthic ecology of a tropical floodplain river. Journal of North American Benthological Society, 25:250-262.

Zaret, T. M. 1980. Life-history and growth relationships of Cichla ocellaris, a predator South American cichlids. Biotropica, 121:144-157.

Submitted December 9, 2010

Accepted May17, 2011

Published September 16, 2011 
Appendix 1. List of fish species indentified in the stomach contents of four focal species. Items are reported as percent (\%) diet composition based on dietary volumetric proportions. Unidentified fish and crustaceans were excluded from family level quantification. Name abbreviations: Cichla temensis (C.tem), Cichla orinocensis (C.orin), Boulengerella cuvieri (B.cuv), and Boulengerella lucius (B.luc).

\begin{tabular}{|c|c|c|c|c|c|c|c|c|c|c|c|c|}
\hline & \multicolumn{4}{|c|}{ Cinaruco } & \multicolumn{4}{|c|}{ La Guardia } & \multicolumn{4}{|c|}{ Ventuari } \\
\hline & C.tem & C.orin & B.cuv & B.luc & C.tem & C.orin & B.cuv & B.luc & C.tem & C.orin & B.cuv & B.luc \\
\hline \multicolumn{13}{|l|}{ Order Clupeiformes } \\
\hline \multicolumn{13}{|l|}{ Family Clupeidae } \\
\hline Amazonsprattus scintilla & & & & & & & & & & 0.5 & & \\
\hline \multicolumn{13}{|l|}{ Family Engraulidae } \\
\hline Anchoviella sp. & 1.9 & 1.0 & 3.8 & 1.2 & 1.0 & & 3.7 & & 2.2 & 1.6 & & 3.4 \\
\hline \multicolumn{13}{|l|}{ Order Characiformes } \\
\hline \multicolumn{13}{|l|}{ Family Anostomidae } \\
\hline Anostomus anostomus & & & & & & & & & & 0.5 & & \\
\hline Laemolyta taeniatus & 0.8 & & 1.3 & & & 0.5 & & & & & & \\
\hline Leporinus sp. A & 0.4 & 0.5 & & & 0.5 & 0.5 & & & 0.6 & 0.5 & & 1.1 \\
\hline Leporinus sp. B & 1.1 & & & & & & & & & 0.5 & 1.8 & 1.1 \\
\hline Pseudanos gracilis & 3.8 & 4.0 & & & 0.5 & & & & & & & 1.1 \\
\hline \multicolumn{13}{|l|}{ Family Characidae } \\
\hline Acestrorhynchus microlepis & 0.8 & & & & 0.5 & & & & 1.1 & & & \\
\hline Acestrorhynchus minimus & 1.5 & 1.0 & & 1.2 & 1.4 & & & & 1.7 & 1.1 & 3.6 & 1.1 \\
\hline Brycon falcatus & 0.8 & 0.5 & & & 1.4 & & & & 1.1 & 1.1 & & \\
\hline Brycon pesu & 1.9 & 1.5 & & & & & & & 1.7 & 0.5 & & \\
\hline Bryconamericus sp. & & 1.0 & 2.5 & & & 1.0 & & & 0.6 & 1.1 & 3.6 & 3.4 \\
\hline Bryconops alburnoides & 1.5 & 0.5 & 2.5 & 2.3 & 1.4 & 1.0 & & & 1.7 & 1.6 & 1.8 & 2.3 \\
\hline Bryconops caudomaculatus & 1.5 & 2.0 & & & 2.4 & 0.5 & 2.5 & 1.7 & 1.7 & 0.5 & & \\
\hline Bryconops giacopinii & 0.4 & & & & 0.5 & & & & 0.6 & 0.5 & & \\
\hline Chalceus macrolepidotus & & 0.5 & & & 1.9 & & 1.2 & & & & & \\
\hline Creagrutus phasma & 1.5 & & & & & & & & 1.1 & & & \\
\hline Hemigrammus analis & 1.5 & 2.5 & 8.9 & 9.3 & 2.4 & 2.4 & 6.2 & 11.7 & 5.1 & 5.5 & 12.7 & 5.7 \\
\hline Hemigrammus barrigonae & 0.4 & & 1.3 & & 0.5 & & & & & & & \\
\hline Hemigrammus elegans & 1.1 & 3.0 & 7.6 & 7.0 & 1.9 & 5.3 & 12.3 & 23.3 & 1.1 & 1.6 & 5.5 & 3.4 \\
\hline Hemigrammus micropterus & 0.8 & 2.0 & & 1.2 & & 3.4 & & & & 1.1 & 1.8 & 1.1 \\
\hline Hemigrammus rhodostomus & & & & 1.2 & & 1.9 & 2.5 & & & & & \\
\hline Hemigrammus schmardae & 1.1 & 3.0 & 6.3 & 3.5 & 2.4 & 3.4 & & & 1.7 & 2.7 & 5.5 & 2.3 \\
\hline Hemigrammus stictus & & 0.5 & & 1.2 & & 1.4 & & & 0.0 & 0.5 & & 2.3 \\
\hline Hemigrammus vorderwinkleri & & 1.5 & 12.7 & 10.5 & 4.8 & 5.3 & 3.7 & 5.0 & 5.6 & 9.3 & 10.9 & 10.2 \\
\hline Hemigrammus sp. A & 3.4 & 10.0 & 13.9 & 9.3 & 1.9 & 4.8 & 1.2 & & & 1.1 & & \\
\hline Metynnis hypsauchen & 0.8 & & & & 0.5 & & & & & 0.5 & & \\
\hline Microschemobrycon callops & 2.3 & 3.0 & & 5.8 & 2.4 & 3.8 & 6.2 & 3.3 & & 2.7 & 5.5 & 3.4 \\
\hline Microschemobrycon casiquiare & 1.5 & 2.0 & 2.5 & 1.2 & 1.9 & 1.4 & 1.2 & 1.7 & 1.7 & 1.6 & 5.5 & 6.8 \\
\hline Moenkhausia copei & 1.1 & 2.0 & 5.1 & 4.7 & 4.8 & 7.7 & 9.9 & 13.3 & 5.6 & 4.9 & 10.9 & 5.7 \\
\hline Moenkhausia lepidura & 3.0 & 3.5 & 1.3 & 2.3 & 1.4 & 1.0 & 3.7 & 3.3 & 2.2 & 2.2 & 3.6 & 3.4 \\
\hline Moenkhausia sp. A & 1.1 & 1.5 & 5.1 & 4.7 & 1.0 & 0.5 & 1.2 & & & 1.1 & 7.3 & 4.5 \\
\hline Serrasalmus manueli & 0.8 & & & & & 0.5 & & & 0.6 & & & \\
\hline Serrabrycon magoi & 1.1 & 1.0 & & & 1.0 & 1.4 & & & & 1.1 & & \\
\hline Family Crenuchidae & & & & & & & & & & & & \\
\hline Characidium sp. F & 1.5 & 1.0 & 3.8 & 2.3 & 1.4 & 1.4 & 4.9 & 1.7 & 1.1 & 1.6 & 1.8 & 4.5 \\
\hline Characidium sp. & 0.4 & 1.0 & & & 1.9 & 3.8 & 6.2 & 3.3 & 1.1 & 1.1 & & 3.4 \\
\hline Family Chilodontidae & & & & & & & & & & & & \\
\hline Caenotropus labyrinthicus & 1.5 & & & & & & & & & & & \\
\hline Family Curimatidae & & & & & & & & & & & & \\
\hline Curimata incompta & 1.1 & 0.5 & & 1.2 & & 1.0 & & & & 0.5 & & \\
\hline Cyphocharax oenas & 1.9 & 2.5 & 2.5 & 1.2 & & 7.2 & 14.8 & 15.0 & 6.2 & 4.9 & 7.3 & 6.8 \\
\hline Family Erythrinidae & & & & & & & & & & & & \\
\hline Hoplerythrinus unitaeniatus & & & & & 0.5 & 0.5 & & & & 0.5 & & \\
\hline Hoplias malabaricus & 0.4 & & & & 0.5 & & & & 0.6 & & & \\
\hline Family Hemiodontidae & & & & & & & & & & & & \\
\hline Argonectes longiceps & 1.5 & & & & & & & & & & & \\
\hline Bivibranchia fowleri & 1.5 & 1.5 & 6.3 & 8.1 & & & & & 1.1 & 1.6 & & 4.5 \\
\hline Hemiodus gracilis & 1.9 & 1.0 & 6.3 & 9.3 & 5.7 & 6.3 & 4.9 & 3.3 & 5.6 & 2.7 & & \\
\hline Hemiodus immaculatus & 2.3 & 2.0 & & & 5.3 & 2.4 & & & 1.1 & 0.5 & & \\
\hline Hemiodus semitaeniatus & 0.8 & & & & 2.4 & 1.0 & & & 1.1 & 0.5 & & \\
\hline Hemiodus unimaculatus & 1.5 & 1.5 & & & 12.0 & 2.9 & & & 3.9 & 2.2 & 1.8 & 1.1 \\
\hline Family Lebiasinidae & & & & & & & & & & & & \\
\hline Copella metae & 0.4 & 1.0 & & 1.2 & 1.0 & 1.0 & 1.2 & 3.3 & 1.7 & 4.4 & & \\
\hline Nannostomus unifasciatus & 0.4 & 0.5 & 2.5 & 2.3 & 1.0 & 1.4 & & & 1.7 & 3.3 & & \\
\hline Pyrrhulina lugubris. & 0.8 & & & & & & & & & 0.5 & & 3.4 \\
\hline Family Prochilodontidae & & & & & & & & & & & & \\
\hline Semaprochilodus kneri & 11.3 & 12.5 & & & 12.0 & 7.7 & & & 11.2 & 6.6 & & \\
\hline
\end{tabular}


Appendix 1 (cont.). List of fish species indentified in the stomach contents of four focal species. Items are reported as percent (\%) diet composition based on dietary volumetric proportions. Unidentified fish and crustaceans were excluded from family level quantification. Name abbreviations: Cichla temensis (C.tem), Cichla orinocensis (C.orin), Boulengerella cuvieri (B.cuv), and Boulengerella lucius (B.luc).

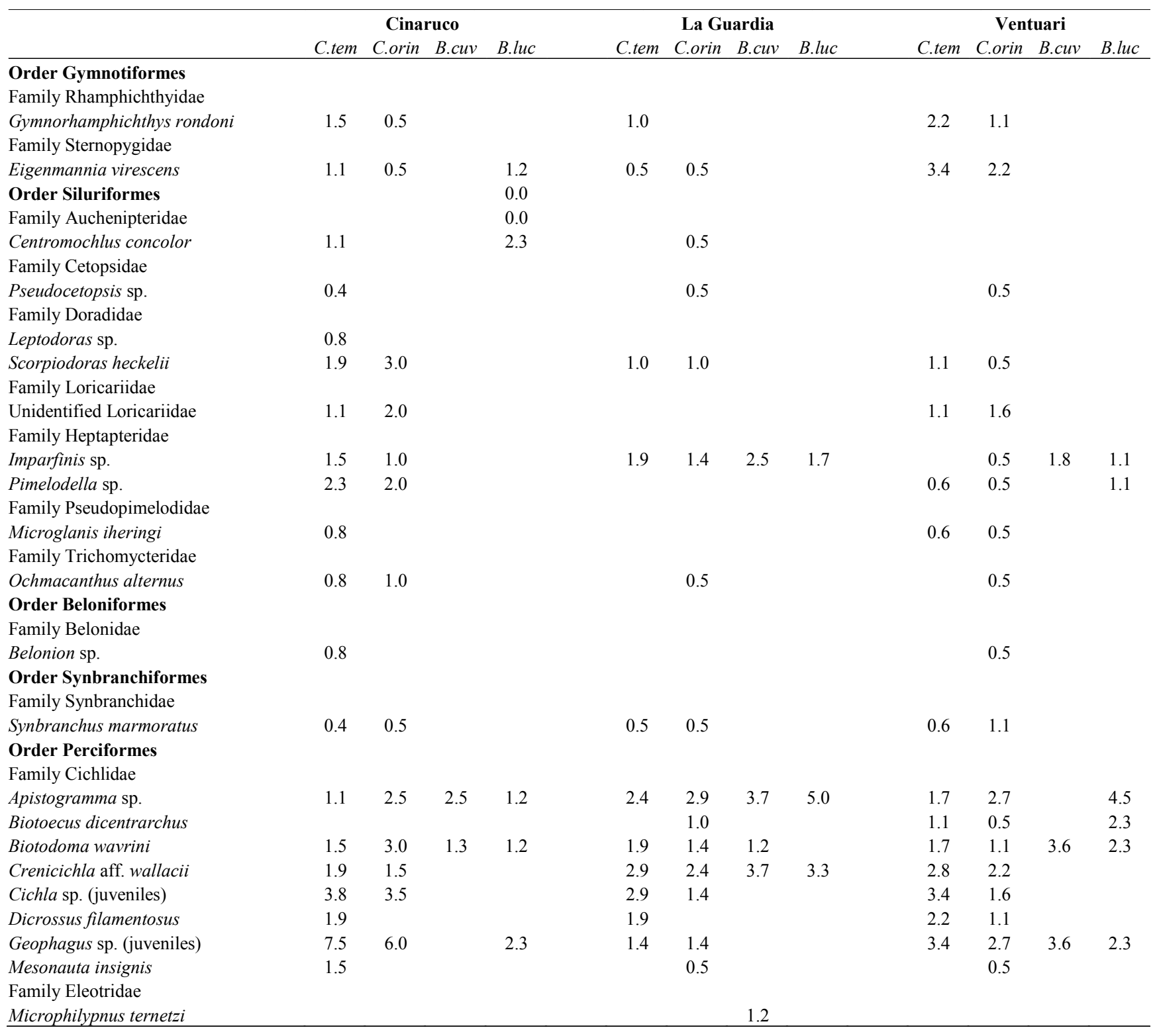

